Artigo de Revisão

\title{
Doenças hereditárias e defeitos congênitos diagnosticados em búfalos (Bubalus bubalis) no Brasil ${ }^{1}$
}

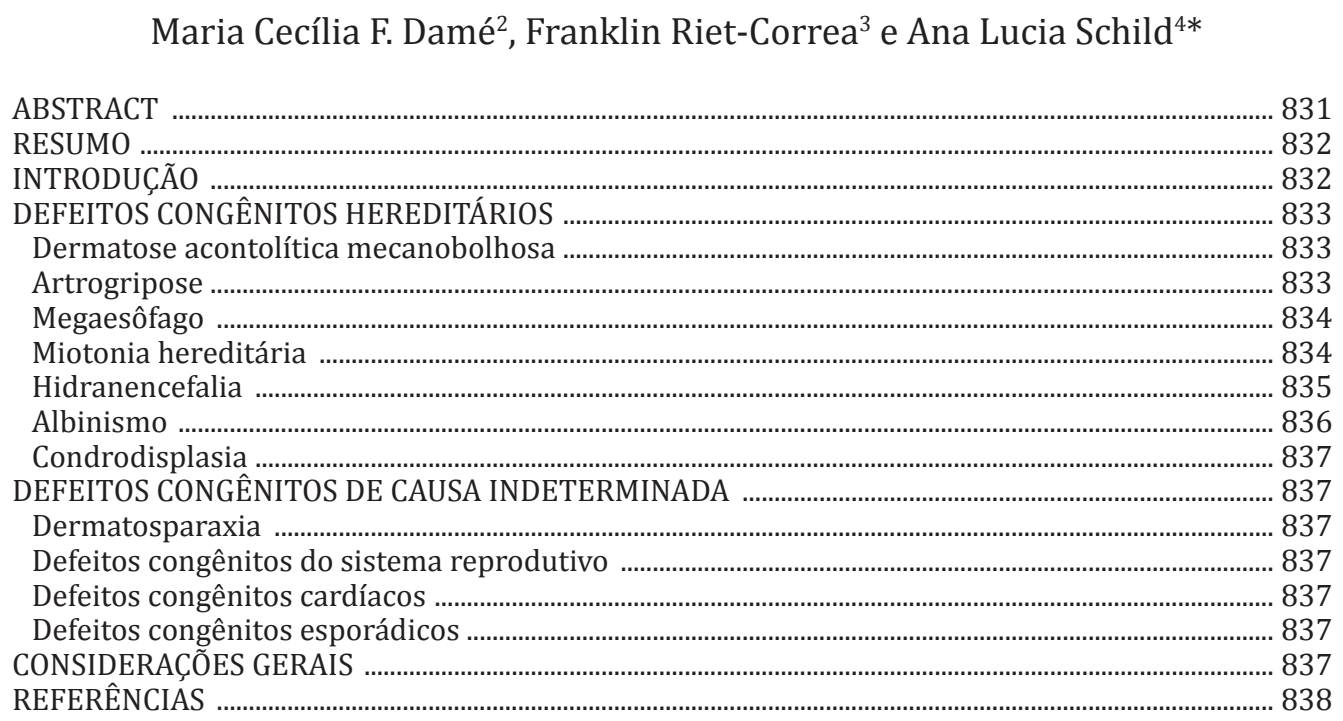

\begin{abstract}
Damé M.C.F., Riet-Correa F. \& Schild A.L. 2013. [Hereditary diseases and congenital defects diagnosed in water buffalo (Bubalus bubalis) in Brazil.] Doenças hereditárias e defeitos congênitos diagnosticados em búfalos (Bubalus bubalis) no Brasil. Pesquisa Veterinária Brasileira 33(7):831-839. Laboratório Regional de Diagnóstico, Faculdade de Veterinária, Universidade Federal de Pelotas, Campus Universitário s/n, Pelotas, RS 96010-900, Brazil. E-mail: alschild@terra.com.br

A review on hereditary diseases and/or congenital defects diagnosed in water buffaloes in Brazil is performed. The epidemiological, clinical and pathological aspects of each disease or group of diseases are briefly described. Hereditary diseases include acantholytic mechanobullous dermatosis, arthrogryposis, myotonia, hydranencephaly, chondrodysplasia, and albinism. Congenital defects of unknown cause include megaesophagus, heart defects (patent ductus arteriosus), dermatosparaxia, and different defects of the reproductive system. The breeds most affected by genetic diseases are those from Asian Continent (Murrah and Jafarabadi), probably as a result of inbreeding in Brazilian herds due the prohibition of importation of breeding buffalo from that continent. The diagnosis of two hereditary diseases, arthrogryposis and myotonia, in Rio Grande do Sul (southern Brazil) and Pará (nothern Brazil) suggests that the undesirable genes are widespread in the buffalo population. The identification of these genes by molecular techniques associated with the buffalo breeding with correct sanitary, zootechnical, and reproductive control practices can decrease the negative effects of genetic diseases in the Brazilian buffalo herd.
\end{abstract}

INDEX TERMS: Congenital defects, hereditary diseases, buffaloes, epidemiology.

\footnotetext{
${ }^{1}$ Recebido em 10 de maio de 2013.

Aceito para publicação em 3 de junho de 2013.

Parte da Tese de Doutorado da primeira autora.

${ }^{2}$ Embrapa Clima Temperado, Rodovia BR $392 \mathrm{Km}$ 78, Caixa Postal 403, Monte Bonito (9o Distrito), Pelotas, RS 96001-970, Brasil. Pós-Graduanda em Veterinária, Faculdade de Veterinária (FV), Universidade Federal
}

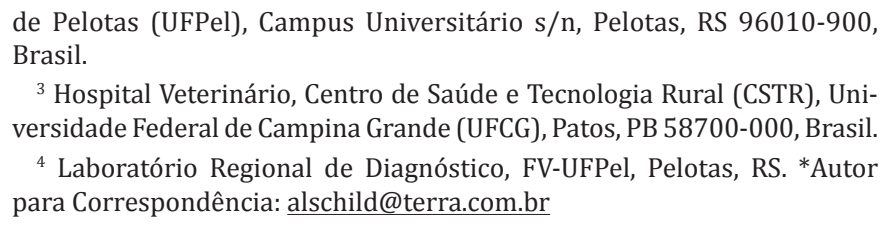

de Pelotas (UFPel), Campus Universitário s/n, Pelotas, RS 96010-900, Brasil.

${ }^{3}$ Hospital Veterinário, Centro de Saúde e Tecnologia Rural (CSTR), Universidade Federal de Campina Grande (UFCG), Patos, PB 58700-000, Brasil.

${ }^{4}$ Laboratório Regional de Diagnóstico, FV-UFPel, Pelotas, RS. *Autor para Correspondência: alschild@terra.com.br 
RESUMO.- É realizada uma revisão sobre as doenças hereditárias e/ou defeitos congênitos diagnosticados em búfalos no Brasil. São descritos brevemente os aspectos epidemiológicos, clínicos e patológicos de enfermidades hereditárias ou provavelmente hereditárias já observadas no Brasil, como dermatose mecanobolhosa, artrogripose, miotomia, hidranencefalia, condrodisplasia e albinismo; e dos defeitos congênitos que não tem uma causa ainda comprovada como megaesôfago, defeitos cardíacos (persistência do ducto arterioso), dermatosparaxia, defeitos no sistema reprodutivo e outros defeitos. Observou-se que as raças mais afetadas por enfermidades de natureza genética são as que têm origem no Continente Asiático (Murrah e Jafarabadi), provavelmente em consequência da consanguinidade existente nos rebanhos devido a proibição da importação de reprodutores, sêmen e embriões daquele continente. 0 diagnóstico de duas dessas doenças, artrogripose e miotomia hereditária no Rio Grande do Sul e no Pará, demonstra que os genes indesejáveis estão disseminados na população de búfalos no país e que a identificação desses genes por meio de técnicas moleculares associada à criação desta espécie com maior controle sanitário, reprodutivo e zootécnico pode minimizar os prejuízos decorrentes dessas enfermidades à bubalinocultura.

TERMOS DE INDEXAÇÃO: Defeitos congênitos, doenças hereditárias, búfalos, epidemiologia.

\section{INTRODUÇÃO}

A população mundial de bubalinos está estimada em aproximadamente 195 milhões de cabeças com a maior concentração no continente asiático (origem da espécie) com 97\% dos animais (FAO 2011).

Essa espécie foi introduzida no Brasil no final do século XIX, na Ilha de Marajó, no estado do Pará. Das aproximadamente 20 raças existentes no mundo, apenas quatro são criadas no país, com registro genealógico junto a Associação Brasileira de Criadores de Búfalos (ABCB): Murrah, Jafarabadi, Mediterrâneo e Carabao. As três primeiras são de pelagem preta e pertencem ao tipo rio e possuem 50 pares de cromossomos e a última pertence ao tipo pântano é de pelagem mais clara e possui 48 pares de cromossomos. Existem, também, animais de pelagem baia, denominados de tipo baio, que juntamente com a raça Carabao correm risco de extinção e estão sendo preservados pela EMBRAPA, no estado do Pará.

Apesar dos bubalinos terem sido introduzidos no país há pouco mais de um século, essa espécie se adaptou a todas as regiões fisiográficas, muitas vezes mostrando desempenho produtivo superior ao apresentado no continente de origem. Em criações extensivas no extremo sul do Brasil apresenta índice de natalidade superior a 90\%, com a primeira cria aos três anos de idade (Damé 2005) e peso de desmame corrigido para 205 dias, em torno de $220 \mathrm{~kg}$ (Damé 2012).

No país, em torno de $85 \%$ dos búfalos são utilizados para corte, sendo abatidos aproximadamente 600.000 animais ao ano com uma produção de carne de aproximadamente 150.000 toneladas (Oliveira 2005) e o restante é explorado para produção de leite, com uma produção anual de 92,3 milhões de litros de leite produzidos por 82.000 búfalas (Bernardes 2007). Na região Norte os búfalos são utilizados, também, para tração.

Junto ao expressivo crescimento do rebanho bubalino brasileiro, em torno de 3,0\% a 3,5\% ao ano (Bernardes 2007), cresceram os problemas decorrentes da consanguinidade, pois o rebanho nacional, estimado em 3,5 milhões de cabeças pela $\mathrm{ABCB}$, originou-se de pouco mais de 200 animais importados. Em consequência do risco da reintrodução da peste bovina, que já tinha ocorrido em 1921 (Riet Correa 2007), a importação de animais do continente asiático foi suspensa em 1956. Em 1962 foi rompida essa proibição e alguns criadores trouxeram alguns bubalinos da Índia (Miranda 1986). Depois disso não houve importação oficial de material genético da Ásia, apenas da Europa. Em 1989 foram importados alguns animais da raça Mediterrâneo da Itália de onde, ainda hoje, há importação de sêmen. Sêmen de búfalos Murrah e Jafarabadi foi importado da Bulgária na mesma época. Esse material só foi liberado pelo Ministério da Agricultura Pecuária e Abastecimento (MAPA) em 1991 (Marques 2012). Por estas razões o rebanho bubalino brasileiro possui uma base genética estreita e consequentemente, a consanguinidade, principalmente em rebanhos de raças puras, vem sendo apontada como o principal fator do aparecimento de várias enfermidades hereditárias nesta espécie animal.

Defeitos congênitos caracterizam-se por anormalidades na estrutura ou função de órgãos, sistemas completos ou parte destes. Estão presentes ao nascimento e podem ocorrer em consequência de fatores ambientais, genéticos ou pela interação de ambos, agindo em um ou mais estágios do desenvolvimento fetal (Leipold et al. 1972, Leipold et al. 1983, Leipold \& Dennis 1986).

A maioria conhecida dos defeitos congênitos hereditários é transmitida por genes recessivos autossômicos, que resultam no nascimento de animais defeituosos, cujos progenitores são normais, sendo a forma mais importante de transmissão hereditária de enfermidades. Esses genes são transmitidos de geração em geração pelos indivíduos heterozigotos e, deste modo, perpetuam-se nas raças das diferentes espécies animais, portanto há necessidade de diagnóstico e identificação das linhagens portadoras dessas anomalias para o desenvolvimento de métodos de controle com a finalidade de evitar a disseminação de genes indesejáveis na população.

Os defeitos congênitos nos bubalinos vêm sendo diagnosticados de norte a sul do país, apesar de algumas vezes esse diagnóstico ser baseado apenas na semelhança com enfermidades já descritas em outras espécies, carecendo de estudos epidemiológicos, patológicos e moleculares que identifiquem o agente ou o gene defeituoso. Diagnósticos têm levado em conta, também, os sinais clínicos apenas no momento em que o animal é examinado, sem o acompanhamento ao longo do seu desenvolvimento e da utilização de técnicas que comprovem o diagnóstico definitivo.

O diagnóstico de certeza dos defeitos congênitos, como em qualquer outra enfermidade, deve envolver uma série de investigações. Além da patologia, a epidemiologia é essencial 
para apontar a etiologia. A formação de um rebanho experimental no sul do país foi fundamental para o diagnóstico, a determinação do tipo de herança e o controle de doenças até então não descritas em bubalinos, como a dermatose acontolítica mecanobolhosa, a hidranencefalia e o albinismo.

Os objetivos do presente trabalho foram revisar as doenças hereditárias e/ou defeitos congênitos diagnosticados em bubalinos no país, abrangendo a epidemiologia, os sinais clínicos, a patologia, o modo de herança e as alterações moleculares, bem como alertar para a possibilidade de disseminação dos genes indesejáveis na população. A literatura sobre a ocorrência desses defeitos no país é escassa e algumas vezes, encontram-se apenas descrições de sinais clínicos. Mesmo assim todas essas publicações foram consideradas nesta revisão.

\section{DEFEITOS CONGÊNITOS HEREDITÁRIOS}

\section{Dermatose acontolítica mecanobolhosa}

Essa doença foi diagnosticada pela primeira vez em um rebanho de búfalos da raça Murrah, na região sul do Rio Grande do Sul (Riet-Correa et al. 1994). Os reprodutores que apresentaram descendentes com essa enfermidade tinham em comum, em sua genealogia, o avô paterno Andad da Cachoeira, primeiro búfalo importado da Índia a receber Registro Genealógico Definitivo (RD 01) pela ABCB. Esse reprodutor, por ser o primeiro a ser registrado, deixou um grande número de descendentes sendo a base genética de muitos criatórios de bubalinos da raça Murrah.

De 1987 a 1991 nasceram, no rebanho experimental criado no sul do Brasil quatro búfalos com dermatose acantolítica mecanobolhosa de um total de 289 (0,72\%). A partir do diagnóstico nesses quatro búfalos, cruzamentos consanguíneos foram realizados para estudar os aspectos clínico-patológicos e o tipo de herança da doença. Os sinais clínicos são caracterizados fundamentalmente pelo desprendimento da epiderme em decorrência de traumatismos na pele aparentemente normal resultando em uma superfície rosada ou avermelhada (Fig.1). Os búfalos nascem sem alterações aparentes, mas ao serem contidos para a identificação, com 2-3 dias de vida o pêlo desprende-se com facilidade e ocorre a lesão na epiderme. Ocorre a perda da vassoura da cauda e em alguns casos dos estojos córneos dos chifres e cascos. Os cascos apresentam deformações e separação da pele do rodete coronário. A pele que já sofreu traumatismos torna-se mais frágil, desprendendo-se com facilidade e não apresenta pêlos (Riet-Correa et al. 1994). 0 estudo histológico das lesões demonstrou que as alterações na pele caracterizam-se por acantólise com separação suprabasilar da epiderme. Na microscopia eletrônica de transmissão foi observado que os hemidesmossomas, os filamentos de ancoramento e as fibrilas de ancoramento, que unem a camada basal à derme, permanecem normais. A região entre o estrato basal e o estrato espinhoso apresenta perda de coesão entre os queratinócitos (Riet-Correa et al. 1994).

Com a evolução da doença, a deformação nos cascos apresenta como consequência alterações nas articulações dos membros, tornando a locomoção difícil, o que leva a um menor ganho de peso. 0 período máximo de sobrevivência desses animais foi de cinco anos. Estudos complementares

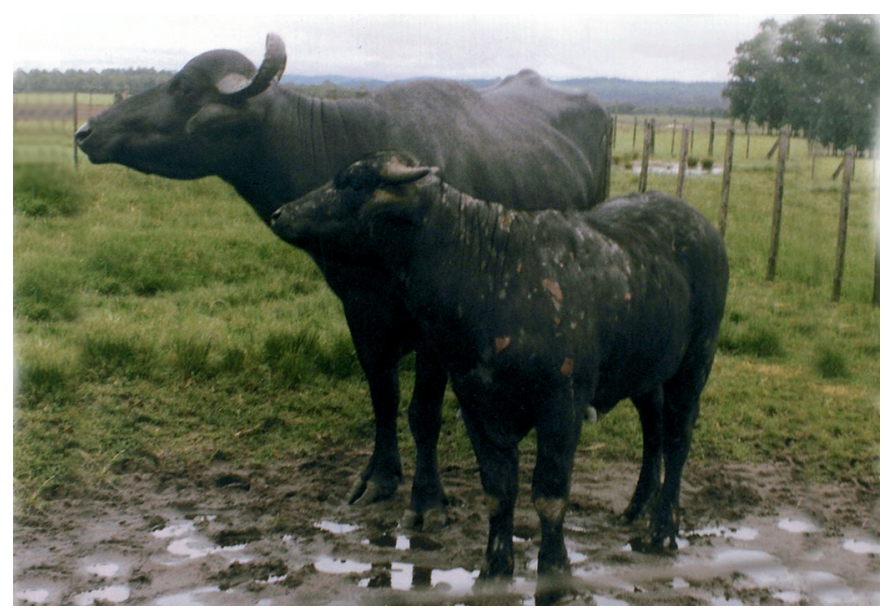

Fig.1. Dermatose acantolítica mecanobolhosa em búfalo Murrah. Há áreas de desprendimento da epiderme deixando uma superfície rosada na região dorso-lateral do corpo do animal, pescoço e face.

demonstram que a doença não apresenta caráter auto-imune e sugerem defeitos na estabilidade, estrutura ou função das caderinas desmossomais e não às alterações nas proteínas da placa desmossomal (Fernandes 2001). Mais recentemente, de acordo com a nova classificação das epidermólises bolhosas em humanos foi postulado que esta enfermidade pode ser definida como uma epidermólise bolhosa simples com separação suprabasal (Medeiros 2012).

0 estudo da genealogia dos búfalos experimentais permitiu concluir que a doença é hereditária, transmitida por um gene recessivo autossômico (Riet-Correa et al. 1994). Após 1998 os búfalos dessa linhagem foram eliminados e não foram mais diagnosticados animais com dermatose acantolítica mecanobolhosa nesse rebanho e não há outros relatos na literatura. Não se pode, no entanto, descartar a possibilidade de ocorrência em outros rebanhos uma vez que, por ser determinada por um gene recessivo autossômico, os casos não são frequentes e equívocos no diagnóstico podem ocorrer.

\section{Artrogripose}

Essa enfermidade foi diagnosticada no rebanho experimental de búfalos da raça Murrah criado na região Sul do Rio Grande do Sul (Schild et al. 2003), tendo sido descrita, também, no Pará (Laú 1999). Entre 1995 e 1998 ocorreram 10 casos em filhos de três touros distintos, mas que tinham parentesco em terceiro grau com o touro Andad da Cachoeira. Metade dos búfalos afetados era filho de apenas um desses três touros. Estudos conduzidos para detectar a origem hereditária da doença não permitiram comprovar essa hipótese, no entanto, várias evidências apontaram para a possibilidade de transmissão por um gene recessivo autossômico. Os búfalos conviviam com um rebanho de bovinos, no qual a doença não foi detectada, descartando-se a possibilidade de causa ambiental para a etiologia da doença dos búfalos (Schild et al. 2003).

Dos búfalos doentes, apenas dois nasceram vivos e apresentavam diferentes graus de rigidez articular dos quatro membros e desenvolvimento reduzido dos múscu- 


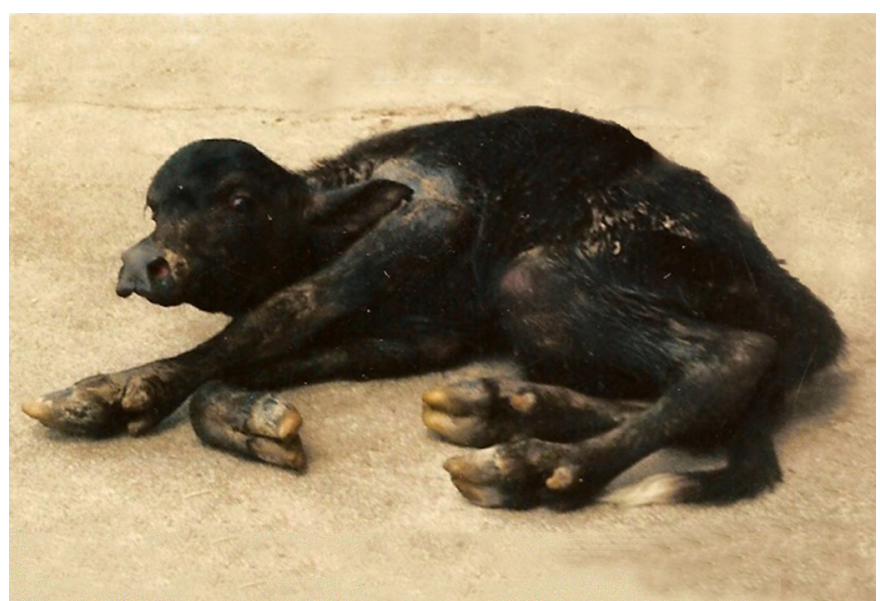

Fig.2. Artrogripose em búfalo Murrah. Há diferentes graus de rigidez articular dos quatro membros e desenvolvimento reduzido dos músculos.

los (Fig.2). Estas alterações podiam ou não estar associadas a prognatismo inferior. Histologicamente não foram observadas lesões no sistema nervoso central e tampouco nos demais órgãos (Schild et al. 2003, Schild 2007).

Após 1998, com a eliminação dos búfalos de linhagens supostamente portadoras do gene transmissor, não foram mais diagnosticados casos de artrogripose no rebanho do sul do Rio Grande do Sul. No Pará a enfermidade foi observada, também, na raça Murrah (Láu 1999). Aparentemente estes fatos reforçam a possibilidade de etiologia genética para a doença.

\section{Megaesôfago}

Megaesôfago foi observado em bubalinos da raça Murrah no rebanho experimental no sul do Rio Grande do Sul, no período reprodutivo de 1994 a 1998. Nesse período, foram utilizados quatro reprodutores, sendo que dois apresentaram descendentes com esse defeito congênito, e tinham parentesco entre si e com o reprodutor Andad da Cachoeira. Todos os animais com essa enfermidade eram filhos de um desses touros e neto do outro. No período nasceram 357 bezerros, sendo 9 doentes, 6 filhos de um reprodutor e 3 do outro, com uma taxa geral no rebanho 2,52\% de animais portadores dessa enfermidade.

Os bezerros com megaesôfago eram filhos de matrizes que criavam mal suas crias, sendo descartadas por esse motivo. Os animais doentes, que atingiram idade de desmama, apresentaram menor peso, em torno de $140 \mathrm{~kg}$, em relação a média de peso de búfalos normais, de aproximadamente $220 \mathrm{~kg}$. A morte ocorria por volta dos sete meses de idade, variando de 3-9 meses. Esses animais apresentavam a cauda mais curta que os demais e não possuíam a vassoura da cauda (Fig.3), mas nem todos os que apresentavam essa peculiaridade fenotípica apresentavam megaesôfago. Além do crescimento retardado, apresentavam timpanismo crônico (Fig.3), sendo esses sinais observados entre 2-6 meses de idade. Havia evidência de regurgitamento e eventualmente pneumonia por aspiração (Schild 2007).

No exame macroscópico, o esôfago apresentava-se dilatado e obstruído por alimentos ressecados e com a musculatura flácida. Havia áreas de congestão, edema e enfisema pulmo-

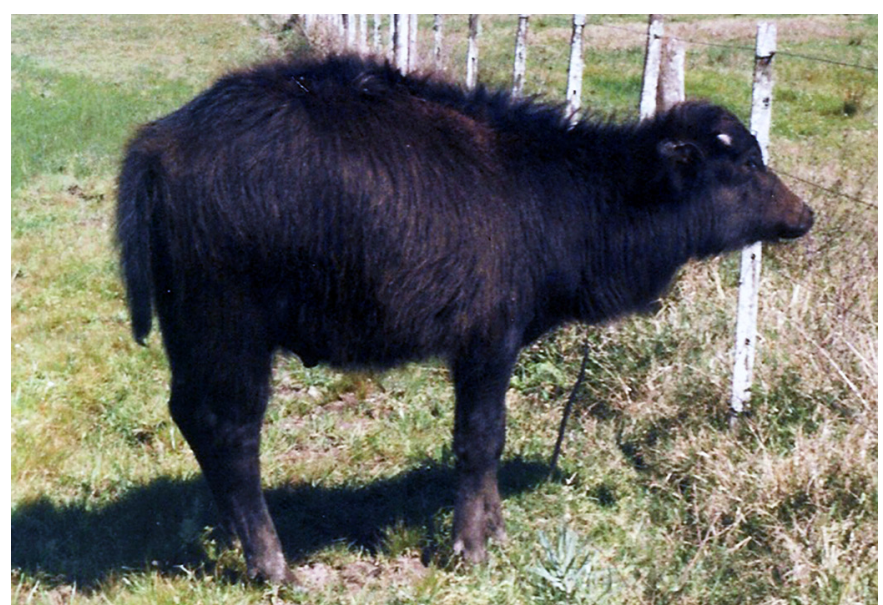

Fig.3. Megaesôfago em búfalo Murrah. Há encurtamento da cauda, timpanismo, evidenciado pelo arredondamento do abdômen, e aumento de volume da porção ventral do pescoço.

nar e líquido na cavidade torácica. Na microscopia do esôfago não foram observadas lesões significativas (Schild 2007).

0 estudo da genealogia dos animais afetados não permitiu concluir se essa enfermidade é de caráter hereditário. No, entanto, os búfalos afetados foram eliminados do rebanho e não foram observados casos novos. Chama atenção que todos os bezerros afetados tinham outro defeito associado e os animais com estas características foram retirados da reprodução o que sugere uma possível causa hereditária para este defeito.

\section{Miotonia hereditária}

Essa enfermidade foi diagnosticada inicialmente como hiperplasia muscular (Barbosa et al. 1999) uma vez que quando o defeito era percebido os animais apresentavam aumento da musculatura, principalmente dos membros posteriores, similar a hiperplasia muscular ou double muscling observada em bovinos e outras espécies inclusive no homem (Rodgers \& Garikipati 2008).

Os sinais clínicos da miotomia hereditária caracterizam-se de modo geral por contrações musculares tônicas no corpo inteiro incluindo os membros, as quais ocorrem quando os animais são estimulados a saírem do estado de repouso. Os búfalos afetados apresentam-se rígidos, movem-se lentamente e com esforço, no entanto a rigidez muscular é menos visível após o exercício, indicando um fenômeno de aquecimento. Os animais apresentam dificuldade para levantar e a rigidez é sempre aparente nos primeiros movimentos após o descanso (Borges et al. 2013). Há queda em decúbito lateral com contração dos músculos dos membros e opistótono, que dura de alguns segundos a no máximo um minuto. As lesões caracterizam-se por músculos semitendinoso e semimembranoso aumentados de tamanho com a pele dessa região mais fina e com menos tecido adiposo (Barbosa et al. 1999). Tem sido observada, também, a ocorrência das crises quando os animais estão em movimento, as quais se intensificam se este movimento é acelerado. A intensidade das crises é, também, variável e podem ser afetados músculos superficiais de grande parte do corpo ou apenas os músculos dos membros posteriores. Nos búfalos cujas contrações 
musculares são acentuadas, podem ser observadas quedas e aumento de toda a musculatura superficial do tronco (Fig.4). Nos búfalos nos quais essas contrações são brandas, não ocorrem quedas, apenas andam alguns segundos com os membros contraídos e esticados e o aumento da musculatura restringe-se aos membros posteriores (Damé 2012). Os búfalos mais agressivos tentam se levantar antes das contrações cessarem e apresentam movimentos de embalar para frente e para trás e de pedalagem dos membros anteriores e caem novamente. Os búfalos dóceis esperam a crise passar para continuar a marcha (Damé 2012).

Os sinais clínicos são semelhantes aos da miotomia hereditária que ocorre nos caprinos e que é determinada por um gene dominante (Radostits et al. 2007). Entretanto, foi demonstrado que a miotonia hereditária dos bubalinos é uma enfermidade de caráter autossômico recessivo e de ampla distribuição nos animais da raça Murrah (Borges 2008, Borges et al. 2013).

As contrações miotônicas são observadas logo após o nascimento e o aumento de musculatura em torno dos 2 a 4 meses de idade, dependendo da intensidade dessas contrações (Damé 2012). Os búfalos afetados podem apresentar porte menor em relação aos normais (Barbosa et al. 1999). Não foram observadas anormalidades encefálicas e em biopsias de músculos de búfalos afetados foi observada hipertrofia de fibras musculares (Borges 2008, Schild 2012).

Em búfalos afetados por miotomia hereditária foi demonstrado, por estudos moleculares, que as descargas miotônicas, detectadas por eletromiografia e a ausência de outras distrofias musculares ou fraqueza muscular, devem-se a anormalidades no gene que codifica os canais de cloro (Borges et al. 2006, Borges 2008, Borges et al. 2013).

No rebanho experimental do Sul da Brasil foram afetados seis búfalos dos quais quatro tinham em comum na sua genealogia o reprodutor Andad da Cachoeira e os outros dois um reprodutor que possivelmente apresenta uma forma branda da doença, na qual não são observadas as crises de contração muscular, mas maior desenvolvimento dos músculos dos membros posteriores chama a atenção.

A avaliação dos parâmetros bioquímicos musculares, he-

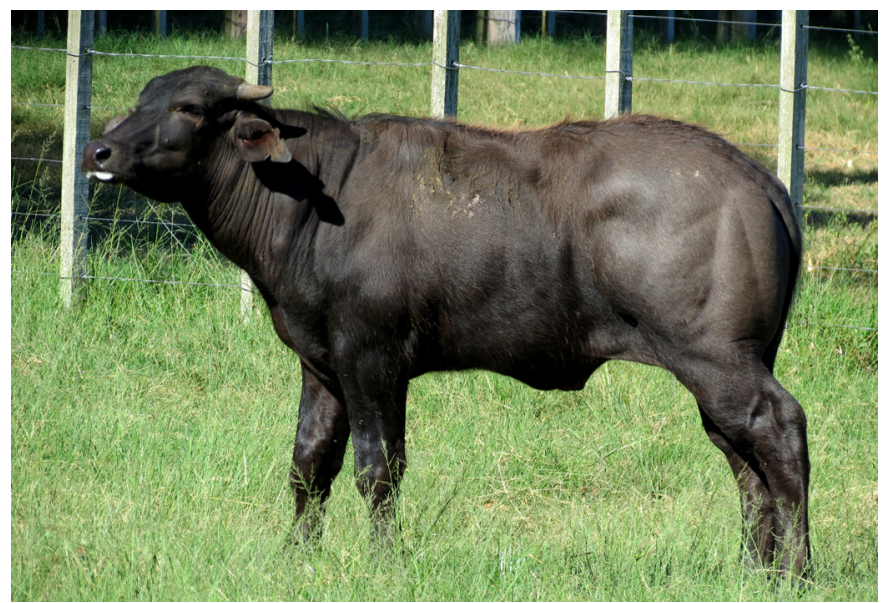

Fig.4. Miotonia hereditária em búfalo Murrah. Há aumento de volume dos músculos dos membros e dos músculos superficiais de todo o corpo. páticos, renais e minerais de búfalos portadores de miotonia hereditária em relação aos normais, mostrou alterações principalmente na atividade muscular (Lima et al. 2011).

A identificação do gene que codifica para a miotonia hereditária é uma forma de controlar a doença pelo rastreamento dos reprodutores portadores do gene indesejável.

\section{Hidranencefalia}

A doença foi observada no rebanho experimental da raça Murrah do sul do Brasil, no período reprodutivo de 2004 a 2009. Nesse período nasceram sete animais afetados (Fiss et al. 2007, Schild et al. 2011). 0 touro pai dos sete bezerros afetados foi acasalado com 20 filhas e sobrinhas para comprovar a possível origem hereditária da enfermidade. Um desses cruzamentos resultou em um bubalino com hidranencefalia e albinismo. No rebanho em que a doença foi diagnosticada eram mantidos quatro lotes de fêmeas com reprodutores distintos. Apenas no lote de um dos reprodutores nasceram animais com hidranencefalia (Schild et al. 2011). Esse animal tinha origem na inseminação artificial com sêmen importado da Bulgária.

Os sinais clínicos da enfermidade foram observados logo após o nascimento e caracterizaram-se por depressão acentuada (Fig.5A), perda do reflexo de ameaça, cegueira,
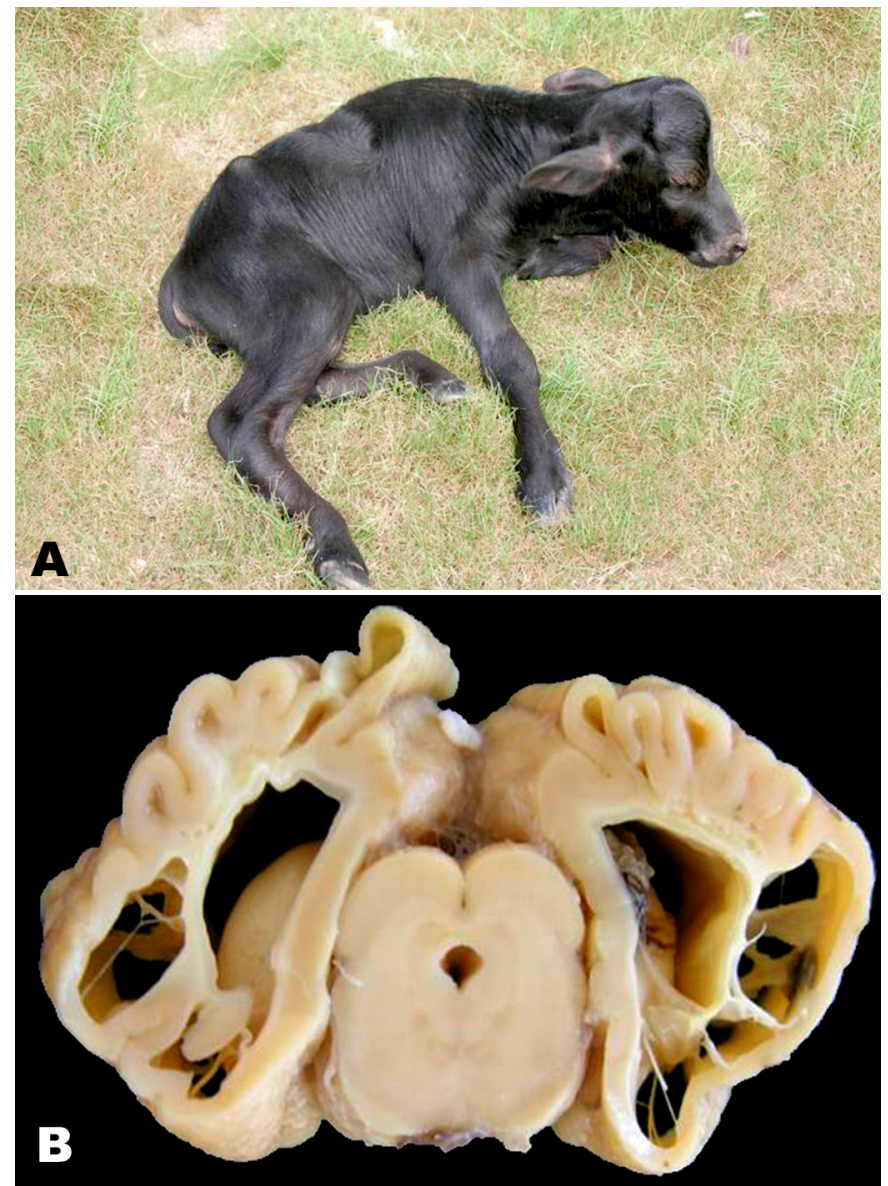

Fig.5. Hidranencefalia em búfalo Murrah. (A) Há sinais neurológicos de apatia profunda e o crânio tem forma de cúpula. (B) Corte transversal do encéfalo apresentando cavidades no tecido nervoso dos hemisférios cerebrais. 0 córtex é estreito e há finos cordões de tecido nervoso atravessando as cavidades. 
decúbito permanente na maioria dos casos e em alguns, estação em base larga e incoordenação com quedas frequentes para frente ou para traz, permanecendo deitados em posições variadas, como em decúbito lateral e com os membros esticados. Havia movimentos rítmicos (tremores/balanço) geralmente da cabeça e pescoço e movimentos laterais das orelhas, principalmente quando estimulados. Esses movimentos variavam entre os bubalinos, indo de discretos a acentuados e generalizados (Fiss et al. 2007, Schild et al. 2011).

As lesões macroscópicas são características de hidranencefalia com superfície do córtex cerebral lisa e resquícios de girus, sulcos e fissuras. Os hemisférios cerebrais apresentam-se como sacos membranosos. Remanescentes do tecido neural atravessavam essas cavidades como uma delicada membrana ou finos cordões de tecido nervoso (Fig.5B) (Schild et al. 2011). Na histologia o córtex cerebral remanescente ao redor do ventrículo lateral é composto por tecido nervoso aparentemente normal, bem como, os cordões remanescentes das cavidades. A substância branca apresenta-se rarefeita e são observadas dilatações no espaço perivascular e esferoides axonais. No cerebelo há diferentes graus de hipoplasia (Schild et al. 2011).

Essa enfermidade é provavelmente hereditária, causada por um gene recessivo autossômico. No rebanho no qual a mesma foi diagnosticada não ocorreram novos casos após
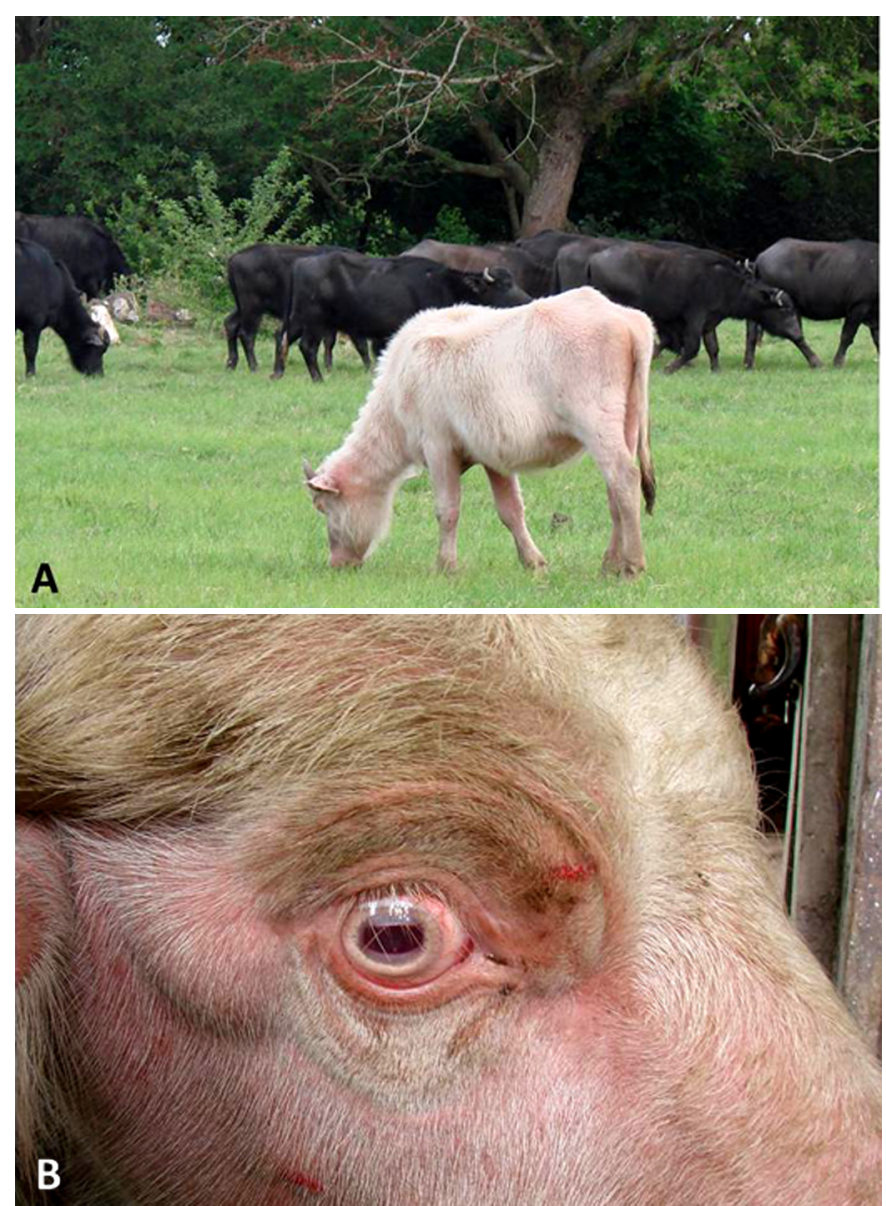

Fig.6. Albinismo em búfalo Murrah. (A) 0 pelo é branco e a pele rosada. (B) Há falta de pigmentação da íris. a eliminação dos pais dos búfalos afetados. No entanto, linhagens portadoras do gene podem estar disseminadas nos rebanhos brasileiros da raça pela estreita relação de parentesco existente entre eles. Essa enfermidade pode estar passando despercebida porque os animais morrem logo após o nascimento e como as búfalas tem o hábito de se esconderem para parir os bezerros não são encontrados.

\section{Albinismo}

No rebanho experimental no Sul do Brasil, albinismo óculo-cutâneo (Fig.6A e B) foi observado pela primeira vez no ano 2000. A partir daí nasceram 11 búfalos afetados até o ano 2012 representando uma prevalência de 1,6\%. Nesse rebanho foi utilizado sêmen de dois reprodutores da raça Murrah importado da Bulgária (Damé et al. 2012). 0 reprodutor, pai de $50 \%$ dos animais albinos havia sido submetido a cruzamento com filhas e sobrinhas para o estudo da hidranencefalia (Schild et al. 2011).

Em bubalinos existem poucas informações sobre a ocorrência de albinismo, sendo descrito o albinismo parcial (Cockrill 1974), cujos animais afetados são denominados albinóides e podem apresentar as mucosas, focinho, olhos e cascos pigmentados ou serem malhados. Barbosa et al. (2005) citam a ocorrência de albinismo ocular e despigmentação da íris em búfalos no Pará. Casos de albinismo em búfalos são descritos, também, na China e na Turquia (Levine 1925, Coban \& Yildz 2005).

Os bubalinos com albinismo óculo-cutâneo apresentam pêlos e extrato córneo dos chifres e cascos brancos e a pele e as mucosas rosadas. Os olhos apresentam a íris cinza pálido e a pupila deixa transparecer uma cor escura. A acuidade visual é reduzida, mas os animais afetados não chegam a esbarrar em obstáculos. Manifestam sinais de fotofobia mantendo os olhos semi-fechados, principalmente, quando expostos à luz solar (Damé et al. 2012).

O albinismo óculo-cutâneo ocorre em consequência de um bloqueio enzimático por mutações no gene da tirosinase (TYR). A falta dessa enzima no melanócito bloqueia a via metabólica que leva a TYR até o pigmento melanina (Borges-Osório \& Robinson 2001, Carden et al. 1998). Nos búfalos da raça Murrah no sul do Brasil foi identificada uma mutação no gene da tirosinase, tendo sido demonstrado, através de análise molecular, a substituição de uma única base no nucleotídeo 1.431, da guanina pela adenina, o que levou a conversão do triptofano (TGG477) em stop codon (TGA477), resultando numa proteína inativa responsável pelo fenótipo do albinismo óculo-cutâneo (Damé et al. 2012).

0 resultado da análise de segregação do rebanho onde ocorreram os casos mostrou que a ocorrência do albinismo deve-se a um gene recessivo autossômico (Damé et al. 2012). A doença está disseminada nos búfalos da raça Murrah, principalmente nos que tem origem búlgara e, em outras raças e mestiços. Foi observado, no Rio Grande do Sul, um rebanho de mestiços onde havia vários animais albinos, incluindo o reprodutor. Os albinos chamam a atenção não só pela pelagem branca, mas também porque na crença popular são considerados animais que trazem sorte ao seu proprietário. 


\section{Condrodisplasia}

Condrodisplasia foi diagnosticada em um rebanho de bubalinos da raça Murrah no estado do Pará. Os animais afetados eram filhos de um reprodutor que apresentava o mesmo problema, sendo que $10 \%$ dos animais do rebanho eram doentes. Os sinais clínicos caracterizavam-se por porte menor com membros mais curtos, encurtamento da mandíbula e maxila. Na necropsia foi constatado encurtamento dos ossos nasais, incisivos, maxilares, dos corpos da mandíbula e das conchas nasais o que levou a alteração na localização dos dentes. Os molares inferiores se estendiam até o ramo da mandíbula e os molares superiores até a abertura orbital do canal supra-orbital (Barbosa et al. 2005).

\section{DEFEITOS CONGÊNITOS DE CAUSA INDETERMINADA}

\section{Dermatosparaxia}

Essa doença foi observada em dois bubalinos, de 15 e 30 dias de idade, no estado do Pará. Os sinais clínicos descritos foram crescimento retardado, lesões de pele que apareciam com facilidade e comprometimento da mobilidade das articulações. A superfície da pele caracterizava-se pela presença de manchas vermelhas e depósito de material seroso na superfície. Na biópsia da pele lesada foram observadas miofibras seccionadas transversamente e irregulares e poucas fibras normais (Láu 1997, 1999). Nesta enfermidade a pele apresenta-se frágil, frouxa e com cicatrização retardada. Aparentemente há um defeito na síntese de colágeno. Na histopatologia as fibras de colágeno encontram-se desorganizadas e fragmentadas (Hargis \& Ginn 2009, Radostits et al. 2007).

A descrição da biópsia da pele não esclarece a patologia da doença e os sinais clínicos (Láu 1997, 1999) são semelhantes aos observados na dermatose mecanobolhosa, o que sugere um equívoco no diagnóstico, embora isso não possa ser confirmado.

\section{Defeitos congênitos do sistema reprodutivo}

Na região amazônica, trabalhos de achados de matadouros, citam vários problemas reprodutivos de origem congênita em bubalinos, tais como: hipoplasia ovariana, anomalias de desenvolvimento dos ductos de Muller (aplasia segmentar da tuba e útero, dupla cérvice, persistência da parede medial dos ductos de Muller), hipoplasia e aplasia testicular, aplasia segmentar dos ductos mesonéfricos e anomalias de posição do escroto, disfunção do epidídimo e dag defect, pseudo-hermafrodita masculino e freemartin (Ohashi et al. 2012, Vale 1988).

\section{Defeitos congênitos cardíacos}

Em Minas Gerais foram descritos dois casos de persistência do ducto arterioso em búfalos Murrah (Ecco et al. 2008). Apesar de ser sugerida uma base genética para o defeito, uma vez que os búfalos afetados eram filhos do mesmo touro, deve ser considerada também a possibilidade de ser um defeito esporádico já que outros casos não foram observados no rebanho.

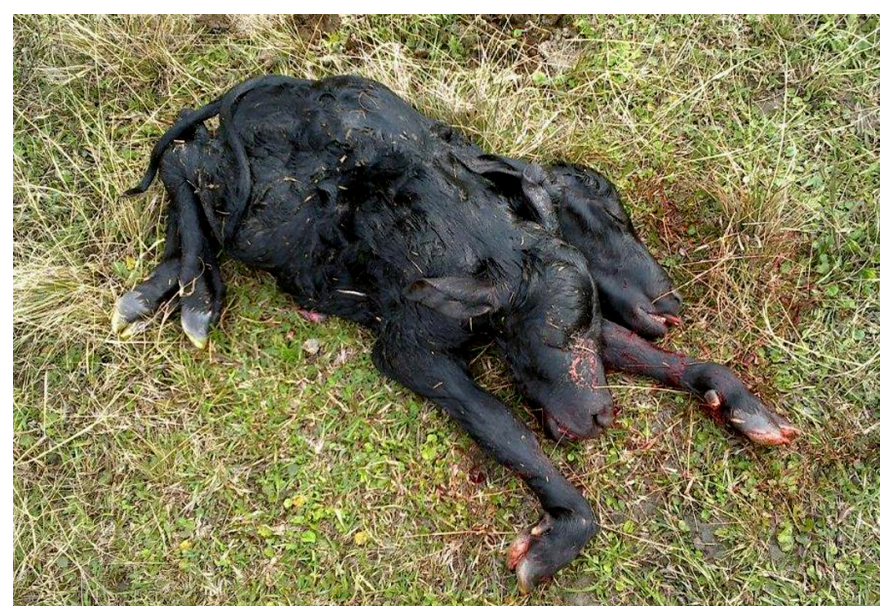

Fig.7. Dicefalia em búfalo Mediterrâneo x Jafarabadi. 0 búfalo apresenta duas cabeças e duas caudas e a coluna vertebral é duplicada.

\section{Defeitos congênitos esporádicos}

Alguns defeitos que ocorrem sem uma causa determinada têm sido observados em rebanhos de búfalos no Pará e no Rio Grande do Sul. No Pará atresia do orifício anal foi observada em uma fêmea bubalina cruza Mediterrâneo de 30 dias de idade que apresentava tenesmo e protrusão da região anal causada pelo acúmulo de fezes e uma fístula reto-vaginal (Láu 1995, 1999). No Rio Grande do Sul uma fêmea da raça Murrah de três dias de idade que apresentava dor abdominal, tenesmo e aumento de volume no períneo, apresentava o orifício anal fechado, causando distensão do reto por acúmulo de fezes e sem fístula reto-vaginal. Uma cirurgia corretiva foi realizada e a fêmea apresentou desenvolvimento semelhante aos demais animais do grupo (Damé 2012).

Dicefalia (Fig.7) foi diagnosticada em um bubalino resultante do cruzamento de uma fêmea da raça Mediterrâneo com um reprodutor Jafarabadi, no Rio Grande do Sul. 0 bezerro nasceu de parto distócico e apresentava duas cabeças, dois pescoços e duas colunas vertebrais cervicais e toráxicas fusionadas a partir da região lombar e divididas novamente na região coccígena formando duas caudas (Damé 2012). Este defeito foi observado, também, na Índia (Srivastava et al. 2008, Sharma et al. 2010) e no Egito (El-Sheikh et al. 2010).

Na raça Jafarabadi, foi relatada por produtores a ocorrência de malformações como dicefalia, polimelia ou polimelia heterotópica, entre outras (Damé 2102).

No estado do Pará foram, também, diagnosticados casos de ataxia do bezerro búfalo, queilognatosquise, hérnia inguinal, hérnia umbilical, anoftalmia e prognatismo mandibular (Láu 1999, Barbosa et al. 2005).

Os defeitos congênitos esporádicos têm pouca importância econômica por ocorrerem com baixa frequência, não só em búfalos, mas também em outras espécies animais.

\section{CONSIDERAÇÕES GERAIS}

A consanguinidade dos bubalinos no Brasil, considerada o fator mais importante para o aparecimento de doenças congênitas, pode ser atribuída basicamente a dois fatores: 
a falta de reprodutores e sêmen de búfalos, principalmente das raças Murrah e Jafarabadi, pela proibição de importação do continente de origem; e, ao emprego de métodos equivocados de criação, uma vez que por serem considerados rústicos, muitas vezes os bubalinos são largados no campo sem controle sanitário, reprodutivo ou zootécnico. Não são raros casos em que são utilizados, como reprodutores, machos do próprio rebanho e, até mesmo, animais portadores de doenças hereditárias, como albinismo e miotonia hereditária. Por outro lado, alguns bubalinocultores têm introduzido reprodutores de raças diferentes nos seus rebanhos para amenizar os problemas decorrentes da endogamia.

A biotécnica da inseminação artificial, apesar de algumas diferenças com a técnica dos bovinos, vem sendo utilizada com sucesso em criatórios mais tecnificados e poderia ser utilizada como uma forma de reduzir a consanguinidade dos rebanhos e assim diminuir a ocorrência dessas enfermidades. Entretanto, é essencial o controle do rebanho, principalmente da genealogia para o planejamento de acasalamentos entre linhagens diferentes.

Pesquisas em melhoramento genético em bubalinos, lideradas pela EMBRAPA e Universidades, focadas na seleção de animais superiores com mapeamento genético poderiam direcionar acasalamentos de animais de linhagens diferentes e livres de genes defeituosos.

Além dos prejuízos econômicos decorrentes das doenças hereditárias descritas no presente trabalho, deve-se levar em conta o comportamento dos búfalos normais em um rebanho frente aos animais que apresentam estes defeitos. Não existem relatos na literatura sobre esse comportamento em relação aos portadores de anomalias congênitas. 0 acompanhamento do rebanho experimental, criado no sul do Rio Grande do Sul, durante um período aproximado de 30 anos, demonstrou que os búfalos doentes são rejeitados pelos sadios. Essa rejeição é observada principalmente nas enfermidades que levam a diferenças fenotípicas marcantes em relação aos normais como o albinismo e a dermatose mecanobolhosa. Quando há casos dessas enfermidades em um rebanho há dificuldade no manejo dos animais quando os mesmos são forçados a se juntarem ao lote. Para os búfalos portadores de miotonia hereditária a rejeição não é tão acentuada, provavelmente porque os animais não apresentam uma diferença marcante em relação aos normais (Damé 2012).

Esse comportamento dos bubalinos, de rejeitar ou abandonar os doentes, pode ser atribuído ao instinto de preservação da espécie. Como tiveram uma domesticação mais recente (Monteiro 2011) preservam, ainda, o instinto selvagem, em que os mais fortes e normais são responsáveis pela perpetuação da espécie.

Através da parceria da Embrapa Clima Temperado com o Laboratório Regional de Diagnóstico da Faculdade de Veterinária, Universidade Federal de Pelotas, foi possível diagnosticar e identificar o tipo de herança e indicar formas de controle de várias enfermidades hereditárias no rebanho experimental como dermatose acantolítica mecanobolhosa, artrogripose, hidranencefalia, miotonia hereditária e albinismo. Recentemente, com as participações da Universidade do Estado de São Paulo e da Universidade Federal da Paraíba foi realizado o sequenciamento do gene defeituoso responsável pelo albinismo óculo-cutâneo (Damé et al. 2012). 0 gene responsável pela miotonia hereditária foi, também, sequenciado (Borges et al. 2013). Em vista disso, atualmente já é possível selecionar reprodutores e matrizes livres de genes que poderiam levar a essas duas enfermidades, sendo esse fato de extrema relevância para o desenvolvimento da bubalinocultura nacional.

\section{REFERÊNCIAS}

Barbosa J.D., Oliveira C.M.C., Duarte M.D. \& Silveira A.S. 2005. Doenças de búfalos na Amazônia. In: II Simpósio Mineiro de Buiatria. Disponível em <www.ivis.org/proceedings/abmg/2005/pdf11.pdf?LA=7> Acesso em 1 out. 2012.

Barbosa J.D., Tury E., Pfeifer Barbosa I.B. \& Cunha Dias V.R. 1999. Hiperplasia muscular congênita (Doppellender, Double Muscling, Culard) em búfalos no Estado do Pará, Brasil. Ciênc. Vet. Trop. 2:50-52.

Bernardes 0. 2007. Bubalinocultura no Brasil: situação e importância econômica. Revta Bras. Reprod. Anim. 31(3):293-298. Disponível em <http://www.cbra.org.br> Acesso em 22 out. 2012.

Borges A.S., Barbosa J.D., Resende L.A.L., Mota L.S.L.S., Amorim R.M., Carvalho T.L., Garcia J.F., Oliveira-Filho J.P., Oliveira C.M.C., Souza J.E.S. \& Winand N.J. 2013. Clinical and molecular study of a new form of hereditary myotonia in Murrah water buffalo. Neurom. Disord. 23:206-213.

Borges A.S. 2008. Estudo clínico, morfológico e molecular da miotonia hereditária em búfalos da raça Murrah. Tese de Livre Docente em Clínica de Equinos e Ruminantes, Faculdade de Medicina Veterinária e Zootecnia, Universidade Estadual Paulista, Botucatu. 94p.

Borges A.S., Mota L.L., Barbosa J.D., Magno C., Amorim R.M., Teixeira R., Mortari A.C., Rahal S. \& Resende L.A. 2006. Nova desordem miotônica em búfalos: descrição clínica e eletromiográfica. Sexto Encontro da Sociedade Brasileira de Investigação Neurológica, Riberão Preto, SP. (Resumo)

Borges-Osório M.R. \& Robinson W.M. 2001. Genética Humana. 2 $2^{\underline{a}}$ ed. Artmed, Porto Alegre.

Carden S.M., Boissy R.E., Schoettker P.J. \& Good W.V. 1998. Albinism: modern molecular diagnosis. Brit. J. Ophthalmol. 82:189-195.

Coban 0. \& Yildz A. 2005. Albinism in an Anatolian buffalo calf. J. Appl. Anim. Res. 27:61-62.

Cockrill W.R. 1974. Observations on skin colour and hair patterns, pp. 4856. In: Cockrill W.R. (Ed.), The husbandry and health of the domestic buffalo. FAO, Rome.

Damé M.C.F. 2005. Principais resultados de pesquisas, manejo e índices zootécnicos dos bubalinos da Embrapa Clima Temperado. Documentos 147, Embrapa Clima Temperado, Pelotas. 36p.

Damé M.C.F. 2012. Comunicação pessoal (Embrapa Clima Temperado, Cx. Postal 403, Pelotas, RS 96001-970).

Damé M.C.F., Xavier G.M., Oliveira-Filho J.P., Borges A.S., Oliveira H.N., Riet-Correa F. \& Schild A.L. 2012. A nonsense mutation in the tyrosinase gene causes albinism in water buffalo. BMC Genetics 13:62. Disponível em <http://www.biomedcentral.com/1471-2156/13/62>

Ecco R., Snel-Oliveira M.V., Barros R.M. \& Santos Junior H.L. 2008. Patent ductus arteriosus in Murrah Buffalos. Vet. Pat. 45:542-545.

El-Sheikh H., Hegab A.O. \& Zaabel S.M. 2010. Dicephalic atlodymus monster associated with hydrops amnii in a buffalo cow: a case report. Vet. Res. 3(4):46-48.

FAO 2011. Food and Agriculture Organization of the United Nations. Disponível em < http://www.fao.org/corp/estatistics/en/> Acesso em 18 abr. 2013.

Fernandes C.G. 2001. Contribuição ao estudo da patogenia de uma genodermatose mecanobolhosa em búfalos Murrah. Tese de Doutorado em Patologia, Faculdade de Medicina de Botucatu, Universidade Estadual Paulista, Botucatu. 170p.

Fiss L., Damé M.C.F., Grecco F.B., Assis-Brasil N., Soares M.P., Ferreira J.L., 
Raffi M.B. \& Schild A.L. 2007. Hidranencefalia congênita de provável origem hereditária em búfalos Murrah. Anais 13ํㅡㄹ Encontro Nacional de Patologia Veterinária, Campo Grande, MS. (CD-ROM)

Hargis A.M. \& Ginn P.E. 2009. Tegumento, p.1107-1261. In: McGavin M.D. \& Zachary J.F. (Eds), Pathologic Basis of Veterinary Disease. $4^{\text {th }}$ ed. Mosby Elsevier, St Louis.

Láu H.D. 1995. Atresia ani in buffalo: a case report. Buffalo Bull. 14(2):3637.

Láu H.D. 1997. Dermatosparaxis in buffalo: a case report. Buffalo Bull. 16(2):46.

Láu H.D. 1999. Doenças em Búfalos no Brasil: diagnóstico, epidemiologia e controle. Embrapa-CPATU, Belém, e Embrapa-SPI, Brasília. 202p.

Levine C.O. 1925. Albino water buffalo. J. Heredit. 16:66,

Leipold H.W. \& Dennis S.M. 1986. Congenital defects affecting bovine reproduction, p.177-199. In: Morrow D.A. (Ed.), Current Therapy in Theriogenology: diagnosis, treatment and prevention of reproductive diseases in small and large animals. W. B. Saunders Company, Philadelphia.

Leipold H.W., Huston K. \& Dennis S.M. 1983. Bovine congenital defects. Adv. Vet. Sci. Comp. Med. 27:197-271.

Leipold H.W., Dennis S.M. \& Huston K. 1972. Congenital defects of cattle: nature, cause, and effect. Adv. Vet. Sci. Comp. Med. 16:103-150.

Lima D.H.S., Lopes C.T.A., da Silveira J.A.S., Aguiar C.O., Soares P.C., Oaigen R.P., Chaves C.M.O. \& Barbosa J.D. 2011. Perfil bioquímico de búfalos com miotonia hereditária. Vet. Zootec. 18(Supl.3):405-408.

Marques J.B.F. 2012. Comunicação pessoal (Embrapa Amazônia Oriental, Cx. Postal 48, Belém, PA 66095-100).

Medeiros G.X. 2012. Epidermólise bolhosa em animais. Tese de Doutorado em Medicina Veterinária, Centro de Saúde e Tecnologia Rural, Universidade Federal de Campina Grande, Patos. 63p.

Miranda W.C. 1986. Criação de búfalos no Brasil. Editora dos Criadores, São Paulo. 173p.

Monteiro M.S. 2011. Lipidograma e glicemia de búfalos leiteiros criados no Estado de São Paulo: influência de fatores fisiológicos e valores de referência. Dissertação de Mestre em Ciências, Faculdade de Medicina Veterinária e Zootecnia, Universidade de São Paulo, São Paulo. 183p.

Oliveira A.L. 2005. Búfalos: produção, qualidade de carcaça e de carne. Alguns aspectos quantitativos, qualitativos e nutricionais para promoção do melhoramento genético. Revta Bras. Reprod. Anim. 29(2):122-134. Disponível em <www.cbra.org.br> Acesso em 15 set. 2010.

Ohashi O., Miranda M.S., Santos S.D., Cordeiro M.S., Costa N.N. \& Silva T.V. 2012. Distúrbios reprodutivos do rebanho bubalino nacional. Ciênc. Anim. 22(1):171-187. Disponível em <http://www.uece.br/cienciaanimal/dmdocuments/ CONERA_PALESTRA\%20\%2813\%29.pdf> Acesso fev. 2013.

Riet-Correa F. 2007. Peste bovina, p.182-183. In: Riet-Correa F., Schild A.L., Lemos R.A.A. \& Borges J.R.J. (Eds), Doenças de Ruminantes e Equídeos. Vol.1; 3aㅡ ed. Pallotti, Santa Maria.

Riet-Correa F., Barros S.S., Damé M.C. \& Peixoto P.V. 1994. Hereditary suprabasilar acantholytic mechanobullous dermatosis in Buffaloes (Bubalus bubalis). Vet. Pathol. 31:450-454.

Radostits O.M., Gay C.C. \& Hinchcliff K.W. \& Constable P.D. 2007. Veterinary Medicine: a textbook of the diseases of cattle, horses, sheep, pigs and goats. $10^{\text {th }}$ ed. W.B. Saunders, Edinburgh. 2156p.

Rodgers B.D. \& Garikipati D.K. 2008. Clinical, agricultural and evolutionary biology of miostatin: a comparative review. Endocr. Rev. 29(5):513-534.

Schild A.L. 2007. Defeitos Congênitos, p.25-51. In: Riet-Correa F., Schild A.L., Lemos R.A.A. \& Borges J.R.J. (Eds), Doenças de Ruminantes e Equídeos. Vol.2. $3^{\mathrm{a}}$ ed. Pallotti, Santa Maria.

Schild A.L. 2012. Dados não publicados (Laboratório Regional de Diagnóstico, Faculdade de Veterinária, UFPel, Campus Universitário s/n, Pelotas, RS 96010-900)

Schild A.L., Fiss L., Damé M.C., Uzal F.A., Soares M.P., Schuch L.F.D., Flores E.F. \& Riet-Correa F. 2011. Congenital hydranencephaly and cerebellar hypoplasia in water buffalo in southern Brazil. J. Vet. Diagn. Invest. 23:603-609.

Schild A.L., Soares M.P., Damé M.C.F., Portianski E.L. \& Riet-Correa F. 2003. Artrogryposis in Murrah buffaloes in southern Brazil. Pesq. Vet. Bras. 23(1):13-16.

Sharma A., Sharma S. \& Vasishta N.K. 2010. A diprosopus buffalo neonate: a case report. Buffalo Bull. 29(1):62-64.

Srivastava S., Kumar A., Maurya S.K., Singh A. \& Singh V.K. 2008. A dicephalus monster in Murrah buffalo. Buffalo Bull. 27(3):231-232.

Vale W.G. 1988. Bubalinos: fisiologia e patologia da reprodução. Fundação Cargil, Campinas. 86p. 